\title{
LIMNOLOGICAL STUDIES OF THE PELAGIC ZONE OF LAKE TANGANYIKA AT KIGOMA, TANZANIA.
}

\author{
FMM Chale \\ Faculty of Science, Technology and Environmental Studies, The Open University of Tanzania, \\ P.O. Box 23409, Dar es Salaam,Tanzania. francischale@yahoo.com
}

\begin{abstract}
Some limnological parameters and chlorophyll a were determined for twelve months at a pelagic station near Kigoma. Temperatures ranged between $25.7{ }^{\circ} \mathrm{C}$ and $27.3{ }^{\circ} \mathrm{C}$ at the surface, and 24.1 ${ }^{\circ} \mathrm{C}$ and $24.7{ }^{\circ} \mathrm{C}$ at $100 \mathrm{~m}$. Thermal stratification persisted throughout the year with the thermocline oscillating between $15 \mathrm{~m}$ in October and $60 \mathrm{~m}$ in May. Dissolved oxygen concentrations were high at the surface, ranging between $6.59 \mathrm{mg} \mathrm{l}^{-1}$ and $8.15 \mathrm{mg} \mathrm{l}^{-1}$, while at $100 \mathrm{~m}$ the concentrations ranged from less than $0.20 \mathrm{mg} \mathrm{l}^{-1}$ to $1.94 \mathrm{mg} \mathrm{l}^{-1}$. Nitrate-nitrogen

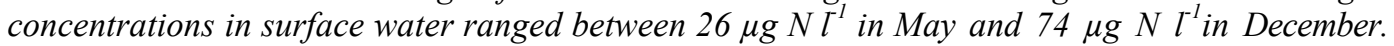
Nitrate -nitrogen concentrations generally increased with depth to $80 \mathrm{~m}$, after which they decreased. Soluble reactive phosphorus concentrations in the photosynthetic zone were always very low, ranging between $0.30 \mu \mathrm{g} P l^{1}$ and $4.0 \mu \mathrm{g} P l^{-1}$. The concentrations increased with depth. Total phosphorus concentrations in the surface water were also low, ranging between 2.0 $\mu \mathrm{g} P l^{-1}$ in March and $12.0 \mu \mathrm{g} P l^{-1}$ in August. The concentrations increased with depth. Chlorophyll a concentrations were generally low throughout the year, except for October and April-May when high concentrations were found. In October the mean concentration was $4.52 \mu \mathrm{g}$ Chl a $l^{-1}$, while January had the lowest concentrations with a mean of $0.36 \mu g$ Chl a $l^{-P}$. Chlorophyll a concentrations decreased with depth.
\end{abstract}

\section{INTRODUCTION}

Lake Tanganyika is the deepest lake in Africa and contains the second largest volume of anoxic water after the Black Sea (Hecky 1991). The lake lies between $3^{0} 31^{\prime}$ and $8^{0} 50^{\prime} \mathrm{S}$ and $29^{\circ} 05^{\prime}$ and $31^{\circ} 15^{\prime} \mathrm{E}$ (Plisner et al. 1999). It is about $650 \mathrm{~km}$ long, with an average width of $50 \mathrm{~km}$, lying at an elevation of $773 \mathrm{~m}$ asl. (Edmond et al. 1993).

In the mixolimnion, the water does not mix completely but there is a stable stratification in the pelagic zone (Coulter 1963). In the northern basin around Kigoma, vertical mixing is confined above the thermocline at 50 to $80 \mathrm{~m}$ (Coulter \& Spigel 1991). It has been shown that in Lake Tanganyika, most of the nutrients are found in the deep monimolimnion (Hecky et al. 1991) and their upward transport occurs mainly during the dry season when maximum circulation takes place (Hecky 1991). Strong south easterly winds blow over the lake between
May and September, causing upwelling in the southern end of the lake (Coulter 163, Hecky op. cit., Coulter \& Spigel op. cit.). However, rainfall is reported to contribute more than $50 \%$ of total dissolved fixed nitrogen in the lake (Edmond et al. 1993; Hecky op. cit.). Hecky and Kling (1981) also reported that nitrogen fixation by Anabaena spp. is likely to be a very important process in the lake.

Chale (2004) reported minimum secchi disc readings and very high chlorophyll $a$ levels in the offshore water around Kigoma in October. The low secchi disc visibility and high chlorophyll $a$ had been shown to be a result of Anabaena spp. blooms which take place during that period (Hecky and Fee 1981, Plisnier et al. 1999).

Phytoplankton biomass expressed as chlorophyll $a$ has been reported to be generally low (Hecky and Kling 1981), with the exception of Octber-November when 
very high concentrations have been found (Chale 2004). These high levels have been attributed to the heterocystous cyanobacteria Anabeana spp. which bloom during that period (Hecky and Fee 1981, Salonen et al. 1999, Hecky 1991).

Kurki et al. (1999) reported cyclopoid copepods to dominate the zooplankton in the pelagic zone throughout the year with peaks in October-November and at the end of the wet season in April and May. The zooplankton could have a negative effect on the phytoplankton due to grazing.

In the following, profiles of monthly limnological data and chlorophyll $a$ in the offshore water of L. Tanganyika near Kigoma are presented. The study was conducted between July, 1998 and June, 1999.

\section{MATERIALS AND METHODS}

The study was carried out at an offshore station about $5 \mathrm{~km}$ from shore where the depth was more than $500 \mathrm{~m}$ (Chitamwebwa 1999). Sampling was conducted in the mixolimnion to the depth of $100 \mathrm{~m}$. In order to minimize changes in the water characteristics, sampling was always carried out between 9:30 am an 10:30 am.

Water temperature and dissolved oxygen were determined at $5 \mathrm{~m}$ intervals using a Yellow Springs Incorporated, Model 50B Dissolved Oxygen Meter with a cord length of $80 \mathrm{~m}$. Temperature and dissolved oxygen values between $85 \mathrm{~m}$ and $100 \mathrm{~m}$ depths were obtained on samples brought on deck the vessel.

Samples nutrients and chlorophyll a were collected at $20 \mathrm{~m}$ intervals using a 7.4 litre capacity (Limnos, Finland) water sampler.
Sample treatments for nitrate-nitrogen, soluble reactive phosphorus and chlorophyll $a$ were carried out as described in Chale (2004).

All sample analyses were carried out in triplicate.

\section{RESULTS}

Surface water temperatures were always high, ranging between $25.7{ }^{\circ} \mathrm{C}$ in August and $27.3{ }^{\circ} \mathrm{C}$ in February (Fig. 1). Bottom water temperatures did not differ much throughout the study period, with values between $24.1{ }^{\circ} \mathrm{C}$ in October and $24.7{ }^{\circ} \mathrm{C}$ in April and May. Thermal stratification was observed throughout the year, though the depths at which the thermocline occurred differed from month to month.

Dissolved oxygen concentrations in the surface water ranged between $6.59 \mathrm{mg} 1-1$ and $8.15 \mathrm{mg} \mathrm{l}^{-1}$ in August and April, respectively (Fig. 2). There was always oxygen at $100 \mathrm{~m}$, though the concentrations differed during the different months. In November, April and May, the oxygen concentrations were $1.94 \mathrm{mg} \mathrm{l}^{-1}, 1.07 \mathrm{mg} \mathrm{l}^{-1}$ and $1.60 \mathrm{mg} \mathrm{l}^{-1}$, respectively at $100 \mathrm{~m}$. Low oxygen was found in October from the depth of $20 \mathrm{~m}$. At $20 \mathrm{~m}$ the concentration was only $3.03 \mathrm{mg} \mathrm{l}^{-1}$.

Nitrate-nitrogen concentrations in surface water ranged between $26 \mu \mathrm{g} \mathrm{l}^{-1}$ in May and $66 \mu \mathrm{g} \mathrm{l}^{-1}$ in December (Fig. 3). From the surface to $40 \mathrm{~m}, \mathrm{NO}_{3}-\mathrm{N}$ concentrations generally increased slightly. But after $40 \mathrm{~m}$ steep increases to $80 \mathrm{~m}$ were observed. For example, the mean $\mathrm{NO}_{3}-\mathrm{N}$ concentration was $61 \mu \mathrm{g} \mathrm{N}{ }^{-1}$, while at $60 \mathrm{~m}$ it was $118 \mu \mathrm{g} \mathrm{N}$ $\mathrm{l}^{-1}$ and at $80 \mathrm{~m}^{\text {it was }} 218 \mu \mathrm{g} \mathrm{N} \mathrm{^{-1 }}$. After 80 $\mathrm{m}$, the concentrations generally decreased. 


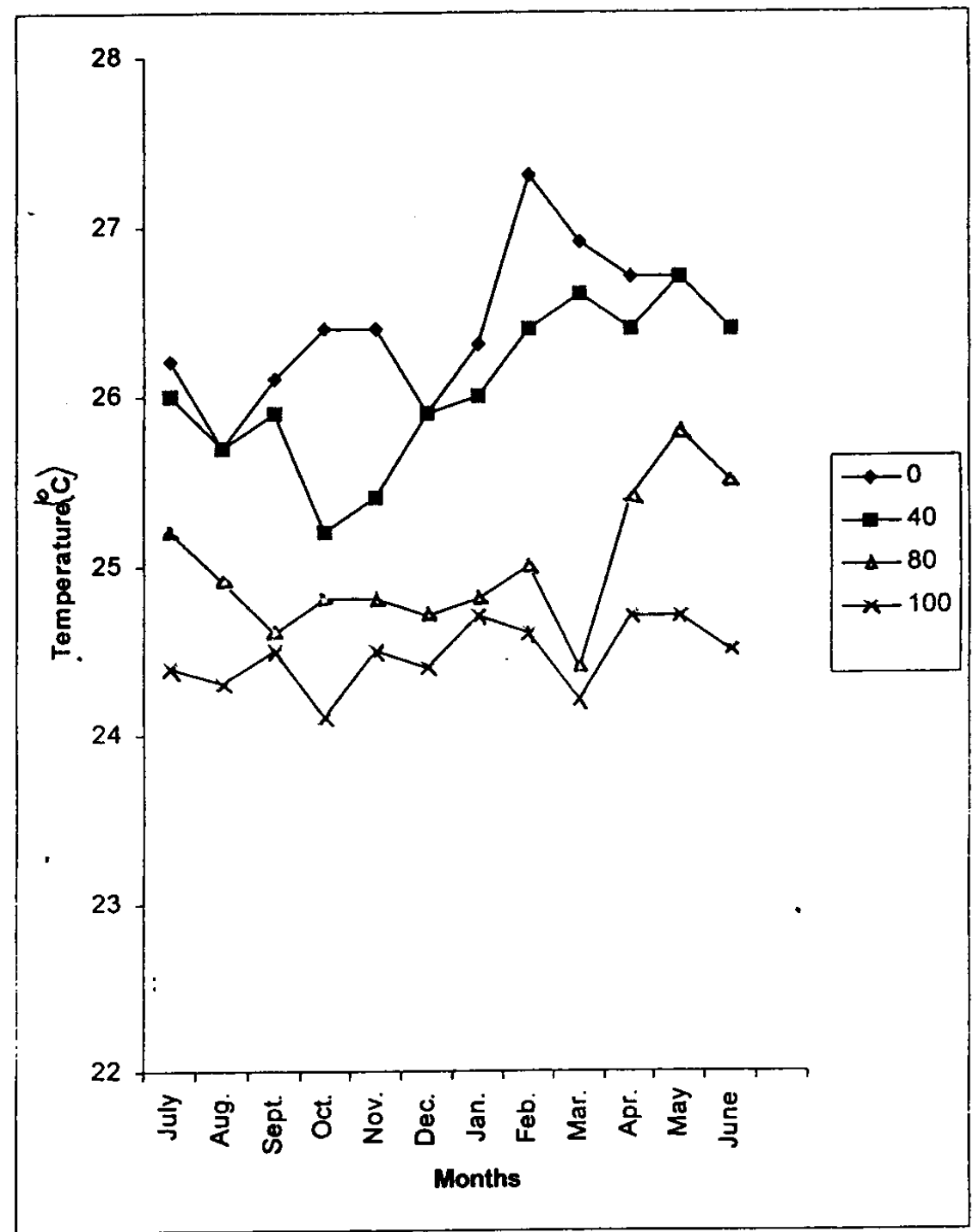

Figure 1: $\quad$ Monthly Temperature $\left({ }^{\circ} \mathrm{C}\right)$ Profiles at Various Depths.

Soluble reactive phosphorus (SRP) concentrations in the euphotic zone were usually very low (Fig. 4). The lowest values were obtained in August, December, January and March, when the concentrations were close to the limit of detection $\left(0.25 \mu \mathrm{g} \mathrm{P}{ }^{-1}\right.$ with a $4 \mathrm{~cm}$ cell). The mean SRP in the euphotic zone was $1.75 \mu \mathrm{g} \mathrm{P} \mathrm{l}^{-1}$.
Chlorophyll $a$ concentrations are presented in Fig. 5. In July, February and March, peak levels were obtained at $40 \mathrm{~m}$. October had the highest levels throughout the water column with a mean concentration of 4.52 $\mu \mathrm{g} \mathrm{Chl} a \mathrm{l}^{-1}$ (range 3.2 and 5.11 $\mu \mathrm{g} \mathrm{Chl} a \mathrm{l}^{-}$ ${ }^{\mu}$. 


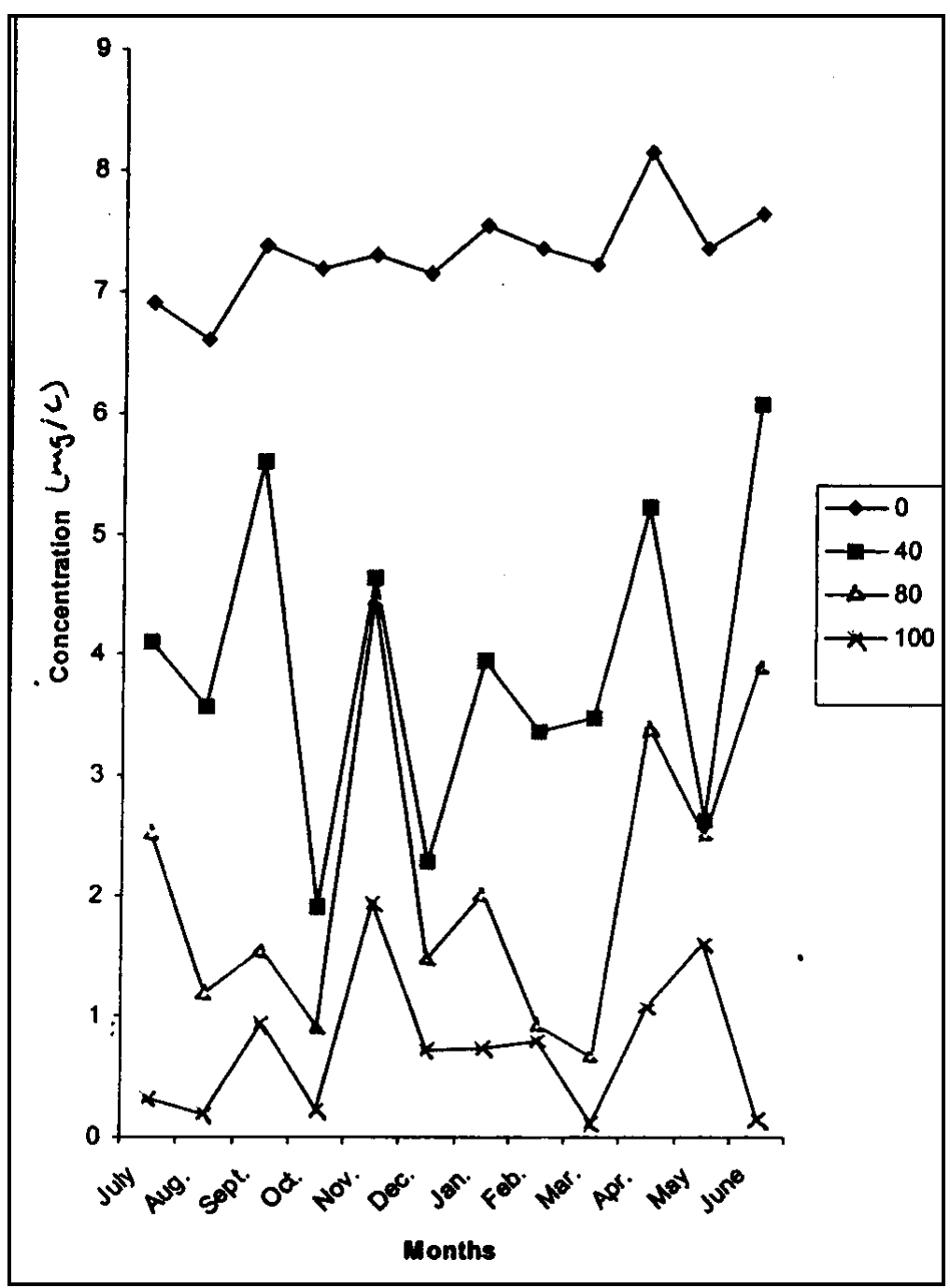

Figure 2: $\quad$ Monthly Dissolved Oxygen Concentrations $\left(\mathrm{mg} \mathrm{l}^{-1}\right)$ with Depth. 


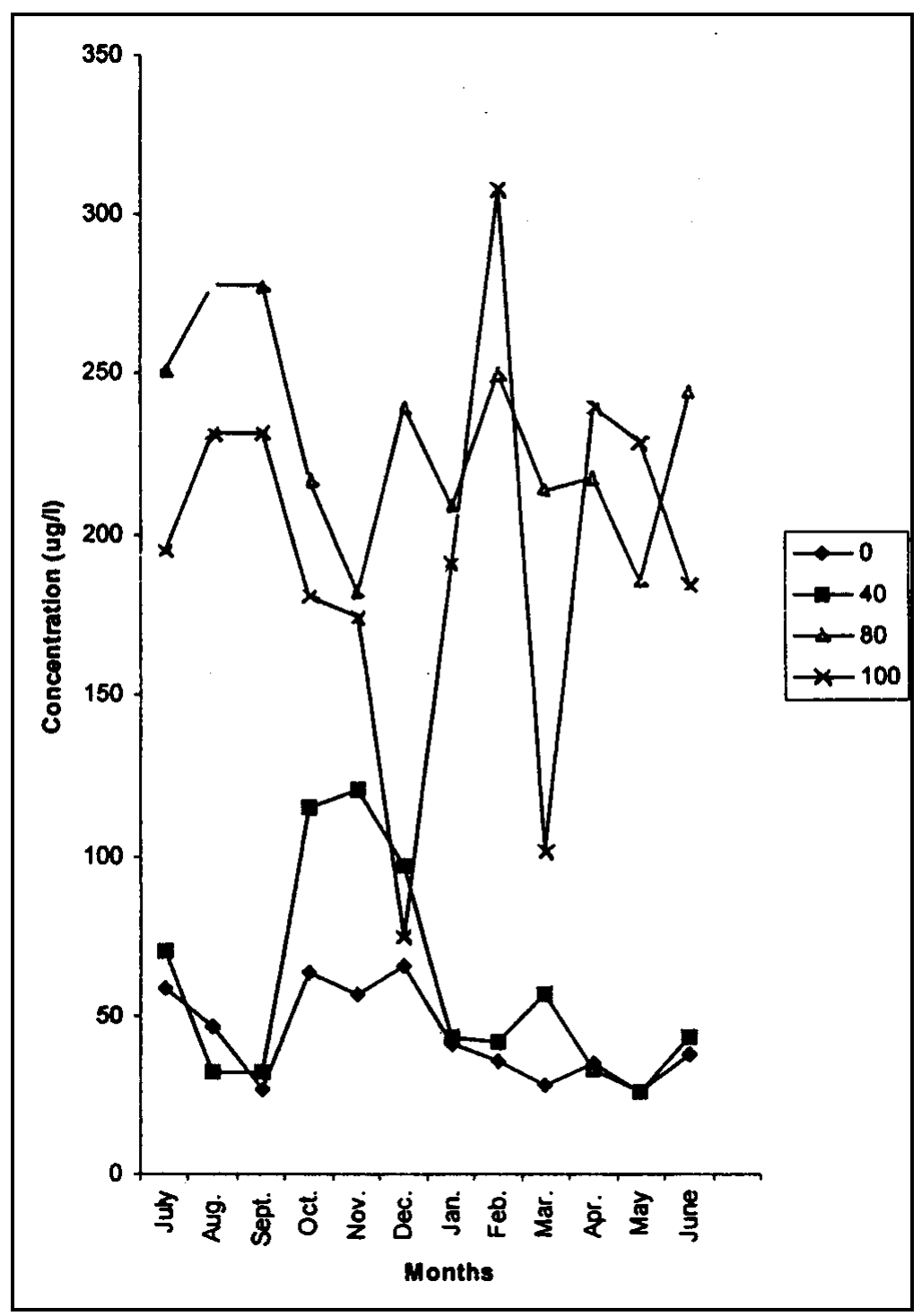

Figure 3: Nitrate- nitrogen $\left(\mu \mathrm{g} \mathrm{l}^{-1}\right)$ with Depth at Sampling Location. 


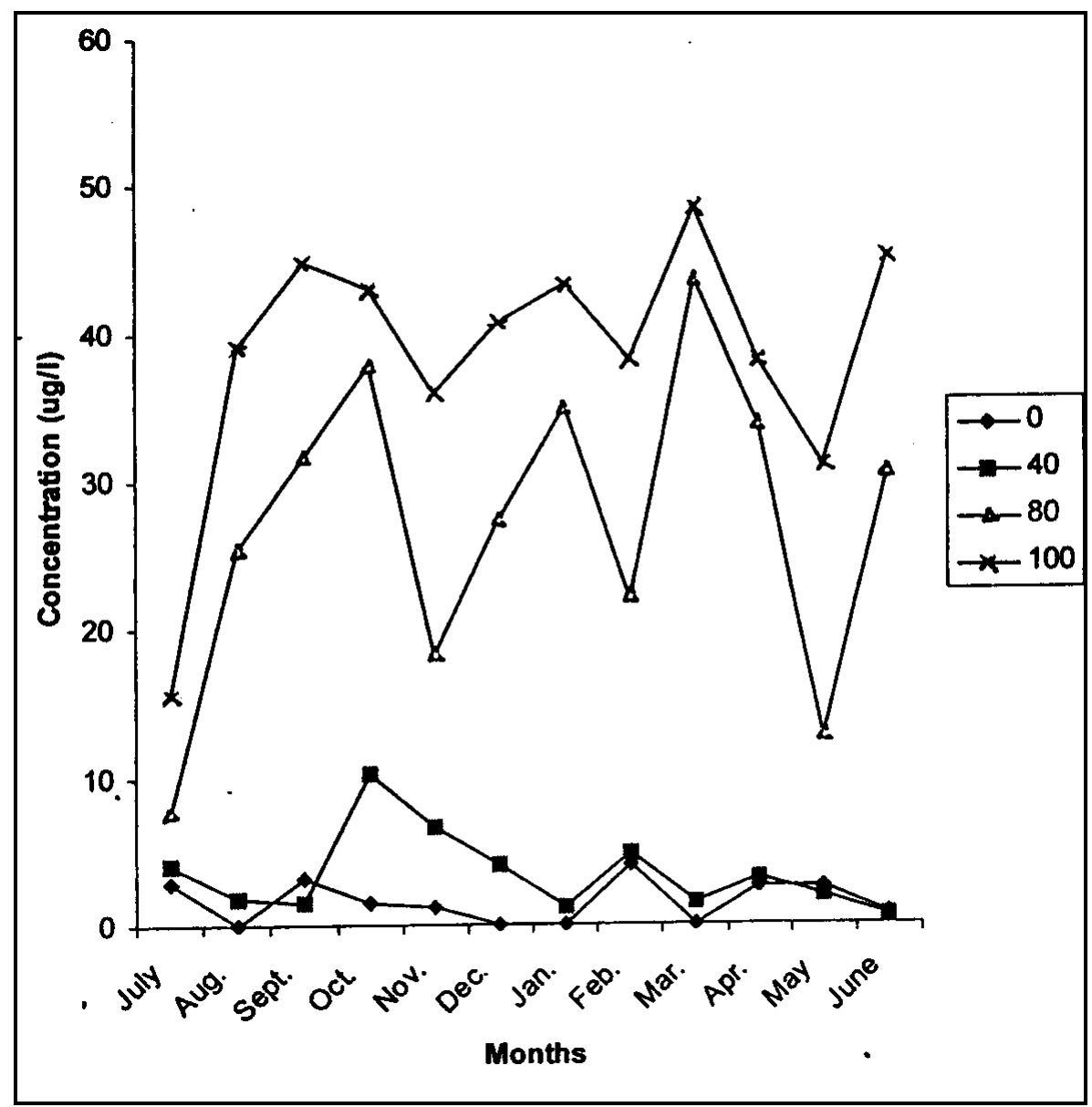

Figure 4: $\quad$ Monthly Soluble Reactive Phosphorus Concentrations ( $\mu \mathrm{g} 11^{-1}$ ) at Sampling Location. 


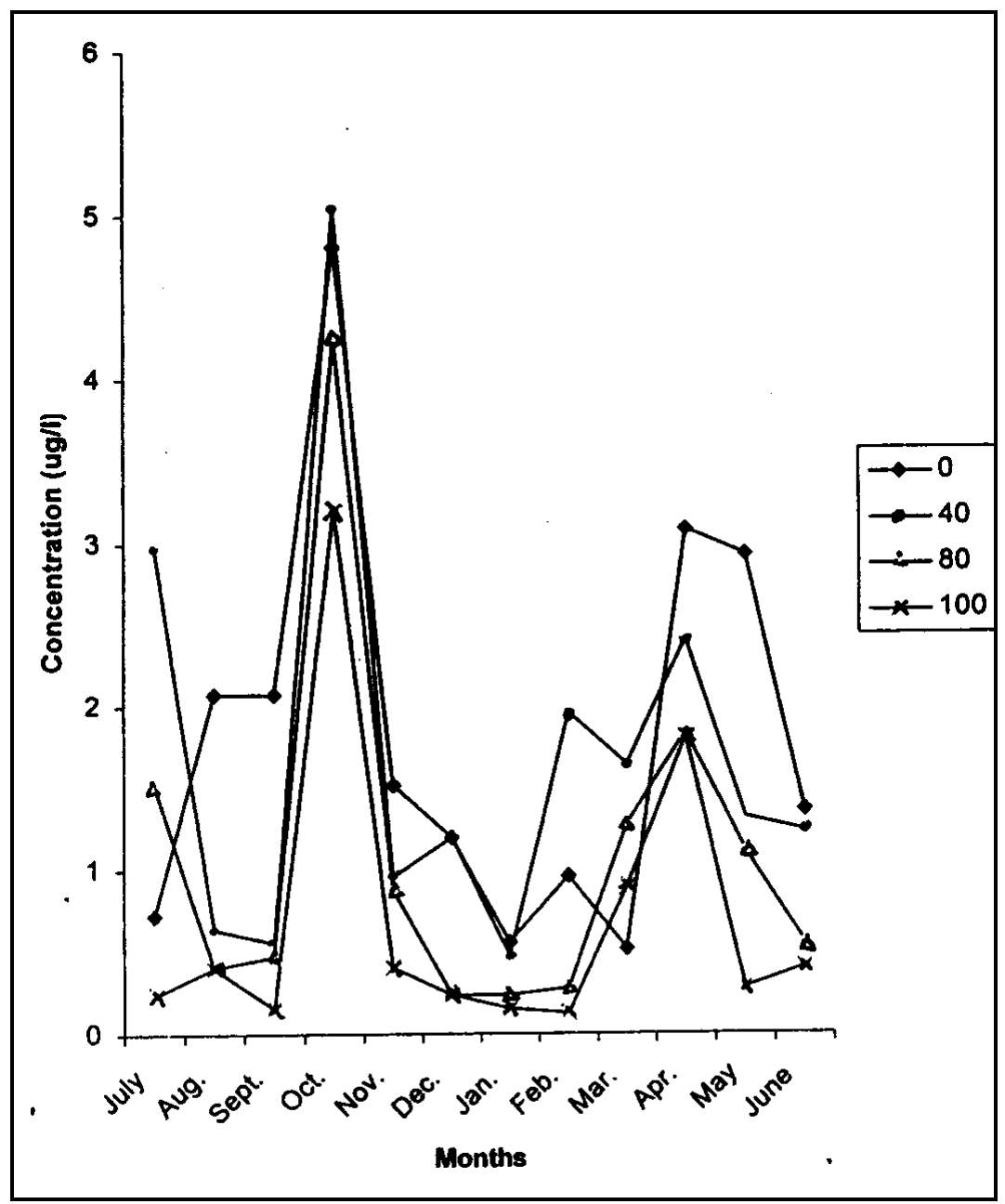

Figure 5: Chlorophyll $a$ Levels $\left(\mu \mathrm{g}^{-1}\right)$ at Sampling Location.

\section{DISCUSSION}

Thermal stratification was observed to persist throughout the year, with maximum depth during the dry season in May and July and also in December. The permanency of the thermocline in the northern basin has also been reported (Coulter 1963, Coulter and Spigel 1991, Chitamwebwa 1999, Plisnier et al. 1999). Coulter and Spigel (op. cit.) stated that stratification was at its maximum during the rainy season. However, Plisnier et al. (op. cit.) observed deepening of the thermocline at Kigoma between November and June. This covered the wet season and part of the dry season. In the present study, the deepening of the thermocline was observed during both periods as reported by Plisnier et al. (1999). The highest surface temperature $\left(27.3{ }^{\circ} \mathrm{C}\right)$ was recorded in February, while the lowest was recorded in August. A similar situation was reported by Coulter and Spigel(1991) for Kigoma. At $100 \mathrm{~m}$, the temperature ranged between $24.1{ }^{\circ} \mathrm{C}$ and $24.7{ }^{\circ} \mathrm{C}$, a range which had been reported before (Chitamwebwa 1999, Edmond et al. 1993). 
In the present study, the thermocline was observed to oscillate between $15 \mathrm{~m}$ and 60 $\mathrm{m}$.

Oxygen was present throughout the study period from surface to $100 \mathrm{~m}$, though the bottom water had very low concentrations. The occurrence of oxygen below the thermocline has also been reported by Coulter (1963). The deeper penetration of oxygen may have been due to ventilation of the metalimnion (Hecky et al. 1991). The low oxygen concentrations found in October from the depth of $20 \mathrm{~m}$ may have been a result of advection of deep water into the metalimnion (Plisnier et al. 1999, Coulter 1963) and also decomposition of dead organic matter. In October, heavy scums of Anabaena spp. were observed in the study area (Hecky and Kling 1981).

Nitrate-nitrogen concentrations in the euphotic zone ranged between $26 \mu \mathrm{g} \mathrm{N}^{-1}$ in may and $74 \mu \mathrm{g} \mathrm{N}^{-1}$ in December. hecky and Kling (1981) reported mean concentrations of total dissolved fixed nitrogen ranging between 49 and $84 \mu \mathrm{g} \mathrm{N}{ }^{-1}$ in the euphotic zone. In the present study high $\mathrm{NO}_{3}-\mathrm{N}$ concentrations were found between $60 \mathrm{~m}$ and $80 \mathrm{~m}$ (Fig.3). The mean nitrate levels at those depths were $118 \mu \mathrm{g} \mathrm{N}$ $1^{-1}$ and $218 \mu \mathrm{g} \mathrm{N}^{-1}$, respectively. Plisnier et al. (1999) reported maximum $\mathrm{NO}_{3}-\mathrm{N}$ concentrations between $60 \mathrm{~m}$ and $80 \mathrm{~m}$ in the north of the lake, while Jarvinen et al. (1999) found higher nitrate levels between $40 \mathrm{~m}$ and $60 \mathrm{~m}$ at Kigoma. In the present study, maximum nitrate concentration was found at $100 \mathrm{~m}$ in February, when the value was $308 \mu \mathrm{g} \mathrm{N} \mathrm{1}^{-1}$. Edmond et al. (1993) reported a maximum $\mathrm{NO}_{3}-\mathrm{N}$ concentration of $154 \mu \mathrm{g} \mathrm{N}^{-1}$ at $96 \mathrm{~m}$ in April at Kigoma. In Lake Tanganyika, rainfall is reported to contribute at least $50 \%$ of total dissolved fixed nitrogen (Hecky 1991, Hecky et al. 1991, Edmond et al. op. cit.). The high levels between October and december could be a result of fixation by Anabaena spp. and rainfall (Edmond et al. op. cit. Hecky op. cit.). The generally low concentrations in the photosynthetic zone may be due to uptake by phytoplankton (Hecky and Kling 1981; Hecky et al. 1991).

In L. Tanganyika, most of the nutrients are in the monimolimnion and their supply to the mixolimnion depends on vertical mixing (Coulter 1963, Hecky et al. op. cit., Edmond et al. 1993, Plisnier et al. 1999). The general decline of nitrate after $80 \mathrm{~m}$ could be due to denitrification processes (Edmond et al. 1993). The low levels of dissolved phosphorus in the epilimnion have been stated to be a result of phytoplankton uptake (Hecky and Kling op. cit., Hecky et al. 1981).

October had the highest concentrations of chlorophyll $a$ throughout the mixolimnion. Peak chlorophyll $a$ levels in the euphotic zone were obtained in October and a small peak in April-May (Chale 2004). Similar observations were reported by hecky and Fee (1981). The high concentration of chlorophyll $a$ in October could have been due to Anabaena spp. which were found to bloom during that period. Hecky and Kling (1981) reported similar observations at Kigoma.In April-May, chrysophytes have been shown to dominate the phytoplankton and Kigoma (Hecky and Kling op. cit.), whose population maximum could be a result of secondary upwelling (Plisnier et al. 1999, Chale 2004). The role of zooplankton to phytoplankton populations in the lake is not well known. Kurki et al. (1999) reported the dominance of cyclopoid copepods in the zooplankton during October-November and April-May. The zooplankton would underestimate phytoplankton biomass through selective grazing.

\section{ACKNOWLEDGMENTS}

This work was carried out while the author was working with the Lake Tanganyika Biodiversity Project. I wish to thank Edmund Kadula and Robert Wakafumbe for sample collection and field measurements, and Elias Lyoba for Chlorophyll $a$ determinations. I also wish to acknowledge 
the help of N. Chale and M. Chatta, who were the crew of R/V "Echo".

\section{REFERENCES}

Chale FMM 2004 Inorganic nutrient concentrations and chlorophyll in the euphotic zone of Lake Tanganyika. Hydrobiol. 523: 189 - 197.

Chitamwebwa DBR 1999 Meromixis, stratification and internal waves in Kigoma waters of Lake Tanganyika. Hydrobiol. 407: 59 - 64.

Coulter GW 1963 Hydrological changes in relation to biological production in Southern Lake Tanganyika. Limnol. Oceanogr. 8: 463 - 477.

Coulter GW and Spigel RH 1991 Hydrodynamics. In Coulter GW (ed.) Lake Tanganyika and its Life. (pp. 49 - 75) Natural Museum Publications, Oxford University Press, London.

Edmond JM, Stallard RF, Craig H, Craig V, Weiss RF and Coulter GW 1993 Nutrient chemistry of the water column of Lake Tanganyika. Limnol. Oceanogr. 38: $725-738$.

Hecky RE 1991 The pelagic ecosystem. In Coulter GW (ed.) Lake Tanganyika and its Life. (pp. $90-110$ ) Natural History Museum Publications, Oxford University Press, London.

Hecky RE and fee EJ 1981 Primary production and rates of algal growth in Lake Tanganyika. Limnol. Oceanogr. 26: $532-547$.

Hecky and Kling HJ 1981 The phytoplankton and protozooplankton of the euphotic zone of Lake Tanganyika: species compostion, biomass, chlorophyll content, and spatio-temporal distribution. Limnol. Oceanogr. 26: 548 - 564.

Hecky RE, Fee EJ, Kling HJ and Rudd JW 1981 Relationship between primary production and fish production in Lake Tanganyika. Trans. Amer. Fish. Soc. 110: $336-345$.

Hecky RE, Spigel RH and Coulter GW 1991 The nutrient regime. In Coulter GW (ed.) Lake Tanganyika and its Life. (pp. 76 - 89) Natural History Museum Publications, Oxford University Press, London.

Jarvinen M, Salonen K, Sarvala J, Vuorio K and Virtanen A 1999 The stochiometry of particulate nutrients in Lake Tanganyika - implications for nutrient limitation of phytoplankton. Hydrobiol. 407: $81-88$.

Kurki H, Vuorinen I, Bosma E and Bweba D 1999 Spatial and temporal changes in copepod zooplankton communities of Lake Tanganyika. Hydrobiol. 407: $105-114$.

Plisnier PD, Chitamwebwa D, Mwape L, Tshibangu K, Langenberg V and Coenen E 1999 Limnological annual cycle inferred from physiclal-chemical fluctuations at three stationsof Lake Tanganyika. Hydrobiol. 407: 45 - 58.

Salonen K, Sarval j, Jarvinen M, Langenberg V, Nuottajarvi M, Vuorio $\mathrm{K}$ and Chitamwebwa DBR 1999 Phytoplankton in Lake Tanganyika vertical and horizontal distribution of in vivo fluorescence. Hydrobiol. 407: $89-103$.

Talling JF 1957 Diurnal changes in stratification and photosynthesis in some tropical waters. Proc. Roy. Soc., B. 147: $57-83$.

Talling JF 1965 The photosynthetic activity of phytoplankton in East African lakes. Int. Revue ges Hydrobiol. 50: 1 - 32 .

Wetzel RG and Likens GE 1991 LimnologicalAnalysis, $2^{\text {nd }} \quad$ Ed. Springer - Verlag, New York. 